野沢 出、岡本 篤、河野 正、矢崎裕久、岡本美孝 ${ }^{1)}$ 、今村俊一 ${ }^{2)}$

1）山梨医科大学耳鼻咽喉科 2）諏訪中央病院耳鼻咽喉科

1.はじめに

日常診療において、急性に発症した比較的軽度の感音難聴例に遭遇することはまれでな い。しかし、一般的には予後良好であり、疾患としてはあまり重要視されない傾向があっ た。小林 ${ }^{1)}$ 、阿部 ${ }^{2} ら$ の報告以来、このような症例が注目され、急性低音障害型感音難聴 (Acute low-tone sensori neural hearing loss、以下ALHLと省略する)という名称で呼び、 我々 ${ }^{3)}$ の報告も含めて、その臨床像、予後、病態等について検討したものがかなりみられ るようになってきた。しかし、このALHLの病態については依然として不明な点も多く、 単に一つの症候なのか、逆に異なった病態の集合としてとらえるものか、さらに、診断基 準に関しても未だに十分な合意を得られていないのが現状と思われる。今回、受診当日に、 グリセロールテストと起立試験を施行しえたALHL症例に関して検討した。

\title{
2. 対象
}

ALHLの診断基準としては、発症より20日以内に受診して、初診時の純音聴力検査で低 音3周波数 $(125,250,500 \mathrm{~Hz})$ の聴力レベルの合計が $90 \mathrm{~dB}$ かそれ以上をしめし、原則として 高音3周波数 $(2000,4000,8000 \mathrm{~Hz})$ の合計が $60 \mathrm{~dB}$ 以下で、鼓膜所見に異常を認めず、ティ ンパノグラムがA型で、気導骨導差がない症例に関して検討した。また、受診時に明らか な回転性めまいを訴え、自発眼振を認めた症例は除外した。また、グリセロールテストは、 グリセオール $200 \mathrm{ml}$ を点滴静注し、点滴前と、終了直後と 1 時間、2 時間後に純音聴力検査 を施行し、2周波数以上でそれぞれ10dBずつ以上の純音聴力閾值の改善がみられた時、陽 性とした。また、起立試験に関しては、患者に仰臥位で10分の安静後、起立させて、1分、 5 分、10分後の血圧及び脈拍数を測定し、収縮期圧低下 $21 \mathrm{mmHg}$ 以上、脈圧狭小化 $16 \mathrm{mmHg}$ 以上、脈拍数増加 21 / 分以上を陽性とした。

3. 結果

1)患側、性別

今回、検討しえた81例の患側は、右耳37例、左耳34例で、両耳罹患例が10例存在した。 また、性別は、男性17例19耳、女性64例72耳で、男女比は、1:3.8 女女性に頻度が高かっ た。全体の平均年歯市、男性43.1歳、女性40.1歳であった。

2)臨床症状

初診時の自覚症状は、耳閉塞感 $68.1 \%$ 、耳鳴 $61.5 \%$ 、難聴 $51.6 \%$ 、立ちくらみ、ふらつ

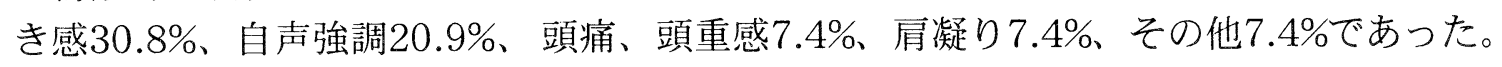

3)初診時の聴力像

初診時の患側の低音 3 周波数聴カレベルの合計の平均は、男性 $121.7 \mathrm{~dB}$ (図 1 )、女性 $116 \mathrm{~dB}$ (図2)であり、健側の低音3周波数聴カレベルの合計の平均は、男性 $53.9 \mathrm{~dB}$ 、女性 $51.6 \mathrm{~dB}$ であった。 
4)グリセロールテスト

グリセロールテスの陽性率は、男性 $9 / 19 耳$ 耳 (47.3\%)、女性 $32 / 72$ 耳（44.4\%）であった。

5)起立試験

安静臥位の収縮期血圧で、100 mmHg以下の低血圧をしめした者は、男性 $23.5 \%$ 、女性 $31.2 \%$ であり、起立試験での陽性率は、男性 $35.3 \%$ 、女性 $53.1 \%$ あった。

\section{unaffected ears

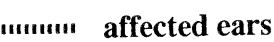

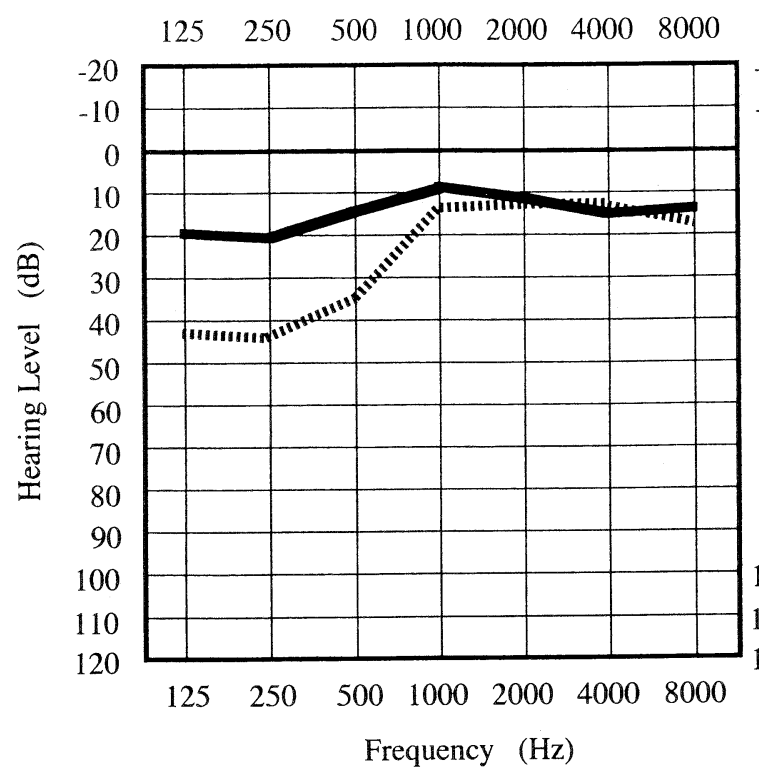

図1 男性の平均聴カレベル

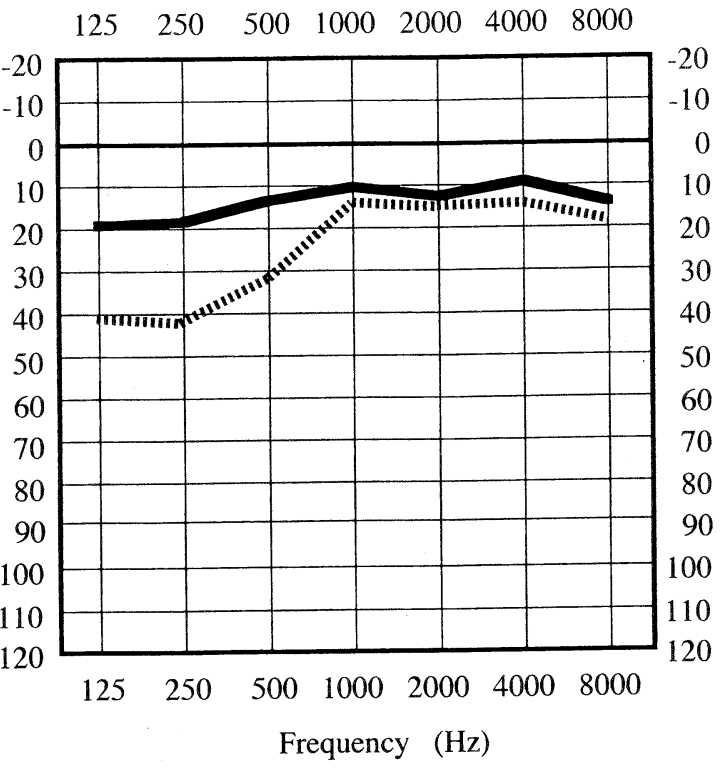

図 2 女性の平均聴カレベル

\section{4. 考察}

今回の検討より、ALHL症例の中には、グリセロールテスト陽性で示されたような内リ ンパ水腫や起立試験で示されたような低血圧症、自律神経失調などがその背景に存在する ことが確認された。ALHLの病態に関しては、一般的には、予後良好な疾患であると考え らているが、その中には、再発例や難治性の改善しない例も存在し、単一の病態で説明す るのがむずかしいのも事実である。しかし、日常診療の中で、見過ごされやすい疾患であ るが、今後さらに増加してくる可能性もあり、病態の解明が必要であると思われた。

(参考文献)

1)小林央雄、小林玲子 : 急性低音障害型感音難聴. 耳鼻 $24: 656-659,1978$.

2)阿部 隆 : 低音障害型突発難聴. 耳喉 $54: 385-392,1982$.

3)Imamura S, Nozawa I et al : Clinical observation on acute low-tone sensorineural hearing loss Survey and analysis of 137 patients. Ann Otol Rhinol Laryngol 106:674-679,1997 